\title{
Pemanfaatan Aplikasi Keuangan di Smartphone untuk Manajemen Keuangan Usaha Pada Kelompok PKK Kelurahan Rambung Barat
}

\author{
Fuzy Yustika Manik1, Dewi Sartika Br. Ginting1, Tetty Yuliaty² \\ ${ }^{1}$ Fakultas Ilmu Komputer dan Teknologi Informasi, Prodi S1 Ilmu Komputer, Universitas Sumatera Utara, Medan, Indonesia \\ 2 Fakultas Ekonomi dan Bisnis, Program Studi Manajemen, Universitas Sumatera Utara, Medan, Indonesia \\ Email: 1,*fuzy.yustika@usu.ac.id, 2dewiginting@usu.ac.id, 3tettyjuliaty@usu.ac.id
}

\begin{abstract}
Abstrak-Tujuan dari pengabdian ini adalah melakukan pelatihan dan pendampingan kepada ibu-ibu anggota PKK untuk mampu mengelola keuangan dan memanajemen keuangan usaha. Metode yang digunakan adalah dengan pendekatan sosial. Dimana dilakukan tahap persiapan dengan melakukan survey dan observasi untuk mengidentifikasi masalah dan menganalisis situasi serta kebutuhan masyarakat. Kemudian dilakukan tahapan pelaksanaan dengan dua kegiatan utama yaitu pelatihan dan pendampingan. Saat pelatihan ibu-ibu anggota PKK diberikan pengetahuan dalam melakukan manajemen keuangan dan mengelola keuangan secara praktis dengan aplikasi. Pendampingan dilakukan saat peserta mempraktekkan langsung penggunaan aplikasi. Berdasarkan evaluasi yang dilakukan, diketahui hasil dari pengabdian ini ada peningkatan pengetahuan dari ibu-ibu anggota PKK tentang manajemen keuangan dengan nilai rata-rata posttest 70 . Melalui pendampingan yang dilakukan masing-masing ibu-ibu anggota PKK tersebut sudah memiliki akun di salah satu aplikasi manajemen keuangan tersebut, dan sudah bisa digunakan untuk pencatatan setiap transaksi, hutang sampai pencatatan stok barang yang masih tersedia.
\end{abstract}

Kata Kunci: Aplikasi; Manajemen; Keuangan; Software; UMKM

Abstract-The purpose of this service is to provide training and assistance to PKK members to be able to manage finances and manage business finances. The method used is a social approach. Where the preparation stage is carried out by conducting surveys and observations to identify problems and analyze the situation and community needs. Then carried out the implementation stage with two main activities, namely training and mentoring. During the training, PKK members were given knowledge in financial management and practical financial management with applications. Assistance is provided when participants practice directly using the application. Based on the evaluation carried out, it is known that the results of this service have increased the knowledge of PKK members about financial management with an average posttest score of 70 . Through the assistance carried out, each PKK member already has an account in one of the applications. financial management, and can be used for recording every transaction, debt to recording stock of goods that are still available.

Keywords: Applications; Management; Finance; Software; UMKM

\section{PENDAHULUAN}

Salah satu dampak Pandemi covid-19 adalah sektor ekonomi yang secara signifikan dirasakan oleh seluruh masyarakat Indonesia, tidak terkecuali oleh masyarakat di Kelurahan Rambung Barat. Banyak tulang punggung keluarga dikelurahan tersebut terpaksa di PHK. Hal ini menuntut seorang istri/ibu untuk berinisiatif mencari jalan mengatasi permasalahan perekonomian keluarga tersebut. Keluarga inti secara tradisional terdiri dari suami, istri, dan anak - anak. Keluarga merupakan bagian penting dalam pengadaan kegiatan ekonomi suatu negara (dewi dkk, 2021).

Sebagian besar ibu-ibu dikelurahan Rambung Barat ikut bergabung menjadi angaota lembaga kemasyarakatan khususnya kelompok Pembinaan Kesejahtraan Keluarga (PKK). Hal ini menuntut seorang istri/ibu untuk berinisiatif mencari jalan mengatasi permasalahan perekonomian keluarga tersebut. Hal ini sesuai dengan program kerja dari PKK yaitu membuat warga masyarakat mampu menciptakan keluarganya menjadi sejahtera dengan meningkatkan kualitas hidup keluarga dan meningkatkan perekonomian keluarganya. Melalui kelompok PKK, ibu-ibu di kelurahan rambung barat diajak untuk bisa menghasilkan dan mengolah produk yang bernilai jual. Dari kemampuan ini ibu-ibu anggota PKK berhasil membuka usaha kecil.

Ibu/istri bertindak sebagai bendahara keluarga yang mengatur dan mengelola keuangan keluarga. Pengelolaan keuangan juga merupakan bagian penting dalam mengatasi masalah ekonomi. Ibu-ibu anggota PKK yang memiliki usaha kecil dituntut untuk mampu mengelola keuangan keluarga secara pribadi dan mengelola keuangan usaha. Di masa pandemi ini tugas ini harus dilakukan dengan baik.

Manajemen usaha sangat diperlukan saat mulai membuka usaha. Saat memulai usaha, pelaku usaha biasanya melakukannya dengan bermodal nekat tanpa dibekali dengan rencana pemodalan jangka panjang maupun kemampuan dan pengetahuan manajerial yang dibutuhkan dalam berwirausaha (Fathah and Widyaningtyas, 2020). Bagi kelompok PKK yang masih mengelola usaha secara pribadi. Dimana pendiri atau pemilik juga merupakan pekerja sekaligus menjadi ibu rumah tangga pengetahuan tentang manajemen keuangan sangatlah minim. Sehingga dalam pengelolaan keuangan yang sangat sederhana masih mencampur adukkan keuangan pribadi dengan keuangan usaha. Hal ini membuat usaha yang dikelola tidak berkembang dengan baik (Kristanti, et all. 2021). Supriyono dkk (2021) juga telah melakukan pengabdian pengelolaan keuangan bagi ibu rumah tangga pemilik usaha UMKM, karena ibu memiliki peran dan andil yang cukup besar dalam semua keluarga. Hetika dkk (2020) melakukan pengabdian dengan memberikan edukasi kepada pelaku Usaha Mikro, Kecil dan 


\section{Journal of Social Responsibility Projects by Higher Education Forum}

Vol 2, No 2, November 2021, Page 68-72

ISSN 2723-1674 (Media Online)

Menengah (UMKM) di Kota Tegal mengenai pentingnya penyusunan laporan keuangan dan memberikan pelatihan penyusunan laporan keuangan secara praktis dengan aplikasi berbasis android. Hasilnya Secara garis besar kegiatan pengabdian ini meningkatkan kesadaran pelaku UMKM untuk melakukan pencatatan keuangan, dan berkontribusi dalam peningkatan ketrampilan pelaku UMKM dalam menyusun laporan keuangan.

Walaupun masih banyak anggota kelompok PKK yang belum mengenal tentang internet dan teknologi. Akan tetapi karena saat ini, setiap individu harus bersiap menghadapi pergeseran kebudayaan dimana setiap pemenuhan kebutuhan harus beriringan dengan perkembangan teknologi. Maka akan penting bagi kelompok PKK untuk menambah pengetahuan tentang pemanfaatan teknologi dalam mengelola keuangan usaha seperti keterampilan dalam mengelola manajemen keuangan dengan memanfaatkan aplikasi. Pemanfaatan aplikasi pengelolaan keuangan memberikan kemudahan bagi ibu-ibu anggota PKK dalam mengelola keuangan usaha. Dengan manajemen keuangan yang baik diharapkan ibu-ibu anggota kelompok PKK dikelurahan rambung barat dapat terus meningkatkan kemampuan dalam mengembangkan usaha yang dapat membantu perekonomian keluarga khususnya dan memperbaiki perekonomian negara yang masih dilanda pandemi covid 19.

\section{METODE PELAKSANAAN}

Metode pelaksanaan yang digunakan dalam kegiatan pengabdian adalah menggunakan metode pendekatan sosial. Pada metode ini, mitra (Ibu-ibu anggota PKK) tidak hanya sekedar menjadi objek kegiatan pengabdian tetapi ikut dilibatkan sebagai subyek kegiatan seperti melibatkan dalam proses persiapan. Hal ini dilakukan untuk menumbuhkan kesadaran bahwa mitra mempunyai masalah dan perlu dilakukan pemecahan masalah. Pendekatan sosial yang digunakan pada kegiatan pengabdian ini juga diperlukan untuk memberi jaminan kelancaran pelaksanaan kegiatan.

Secara garis besar kegiatan pelaksanaan akan dilakukan dalam 3 tahap yaitu Persiapan, Pelaksanaan, Evaluasi dan Pelaporan, seperti dilihat pada gambar 1 di bawah ini:

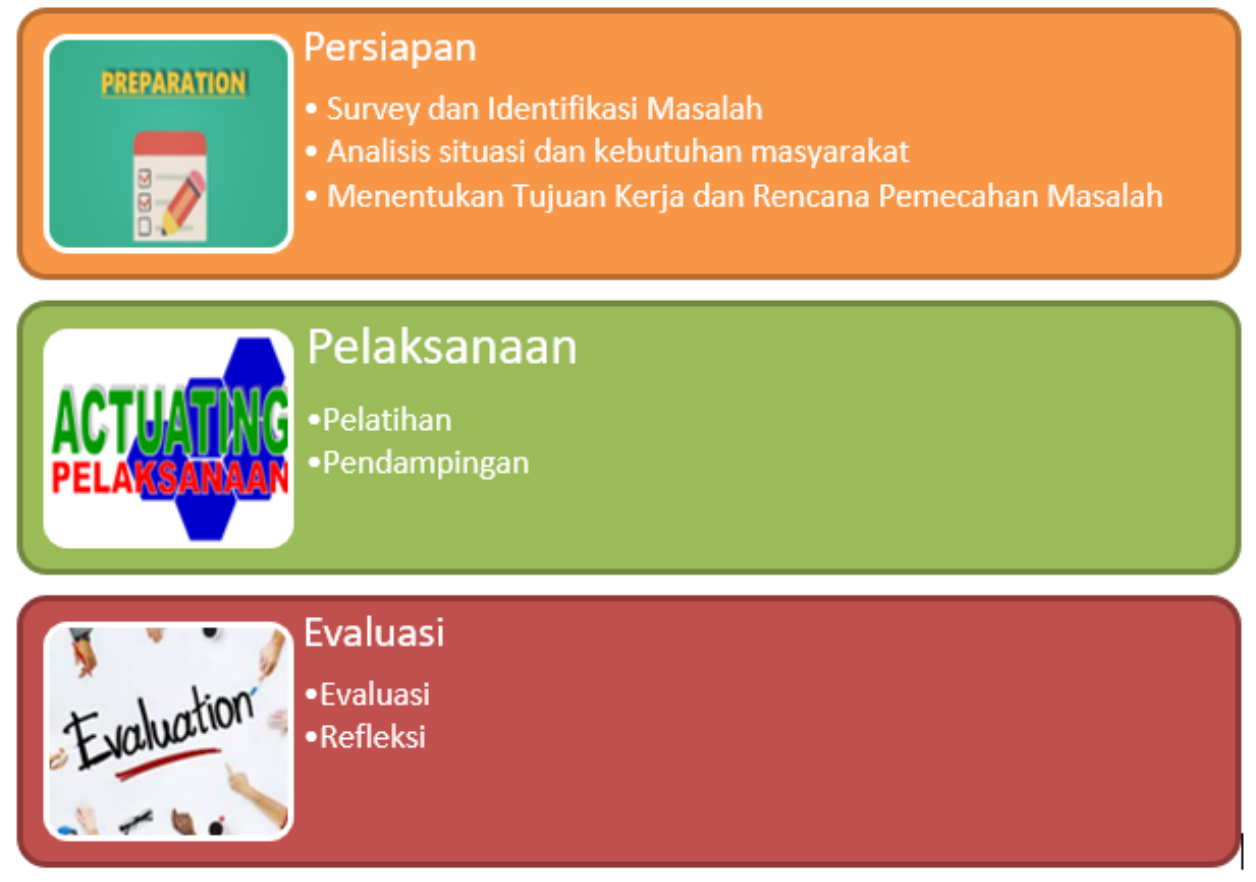

Gambar 1. Tahapan Pengabdian

\subsection{Persiapan}

Pada tahap persiapan langkah pertama yang dilakukan adalah survey dan identifikasi masalah. Survey dilakukan kepada Bapak Lurah Kelurahan Rambung Barat dan Pengurus PKK. Berdasarkan survey diketahui bahwa ada beberapa kelemahan dari anggota PKK dalam mengembangkan usaha. Salah satunya adalah kurangnya pengetahuan tentang mengelola (memanajemen) keuangan usaha. Hal ini dikarenakan masih sering mencampuradukkan keuangan usaha dengan keuangan pribadi serta tidak pernah melakukan pencatatan keuangan.

Berdasarkan permasalahan mitra kemudian dilakukan analisis situasi dan kebutuhan masyarakat. Hasil dari analisis situasi dan kebutuhan masyarakat adalah perlunya menambah pengetahuan tentang manajemen keuangan. Setelah itu dilakukan pemecahan masalah dan tujuan kerja. Pemecahan masalah yang diambil adalah 


\section{Journal of Social Responsibility Projects by Higher Education Forum}

Vol 2, No 2, November 2021, Page 68-72

ISSN 2723-1674 (Media Online)

dengan melakukan pelatihan dan pendampingan. Kemudian mulai dilakukan persiapan bahan materi (modul) dan keperluan lainnya.

\subsection{Pelaksanaan}

Pelaksanaan kegiatan pengabdian dilakukan di aula kelurahan rambung barat binjai selatan. Pelaksanaan kegiatan dibagi menjadi 2 kegiatan utama yaitu pelatihan dan pendampingan. Pelatihan dilakukan dengan penyampain materi oleh narasumber tentang manajemen keuangan dan aplikasi yang bisa digunaka untuk mengelola keuangan dengan mudah.

\subsection{Evaluasi}

Sebelum dan sesudah pemaparan materi, peserta di wajibkan untuk mengisi pretest dan posttest. Hasil pretest dan posttest ini sebagai bentuk evaluasi dari pemahaman peserta. Sedangkan untuk evaluasi kegiatan peserta diminta untuk mengisi kuisoner.

\section{HASIL DAN PEMBAHASAN}

\subsection{Persiapan}

Tahap persiapan dilakukan dengan baik. Mitra baik Bapak Lurah Kelurahan Rambung Barat dan juga pengurus PKK bersikap terbuka dan antusias agar kegiatan pengabdian ini berjalan lancar. Saat melakukan survey dan observasi mitra membantu memberikan semua informasi yang dibutuhkan seperti: penjelasan bagaimana masalah yang terjadi pada ibu-ibu anggota PKK. Ibu-ibu anggota PKK juga dengan terbuka menyampaikan keluhan atau masalah yang mereka hadapi (gambar 2).

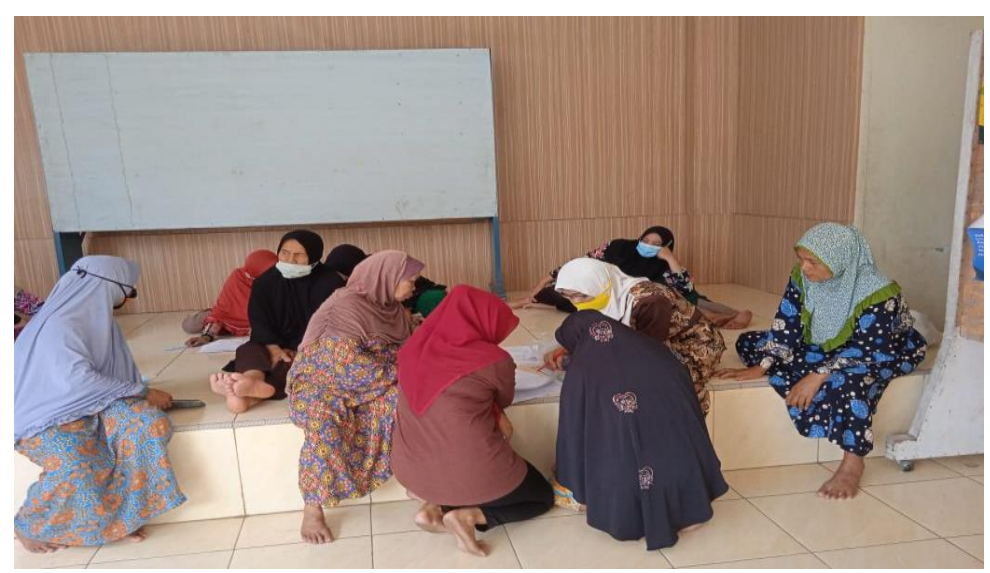

Gambar 2. Survey dan identifikasi masalah pada tahap persiapan

\subsection{Pelaksanaan}

Pelaksanaan kegiatan pengabdian dapat berjalan dengan lancar dengan tetap mengikuti protokol kesehatan. Peserta terlebih dahulu di cek suhu nya dan diminta untuk memakai masker dan mencuci tangan.

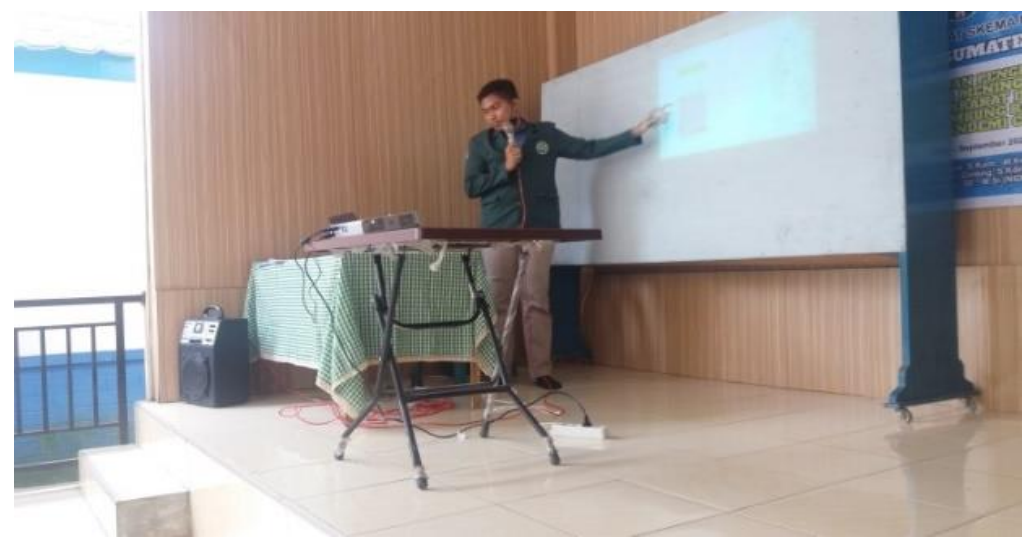

Gambar 3. penyampaian materi oleh salah satu narasumber

Gambar 3 di atas menunjukan pemateri sedang menyampaikan materi tentang manajemen keuangan diikuti dengan aplikasi yang dapat digunakan dengan mudah oleh pengguna. 


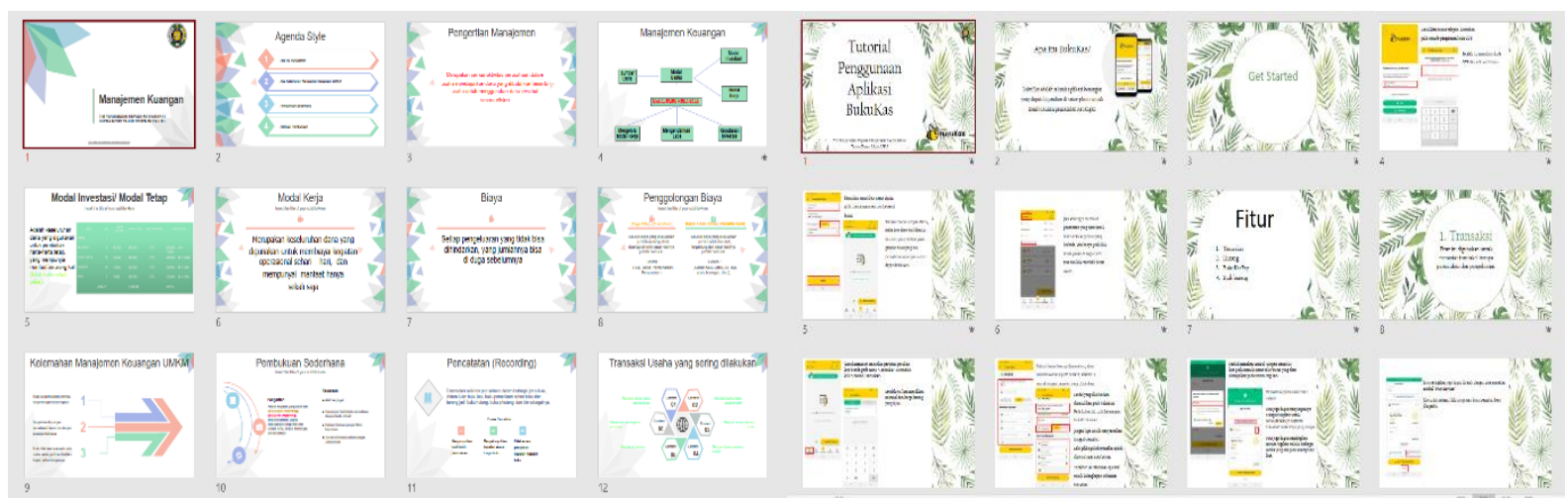

Gambar 4. materi yang disampaikan saat pelaksanaan kegiatan

Materi yang disampaikan dan gaya penyampaian materi sangat disesuaikan dengan para peserta yaitu ibu-ibu anggota PKK. Materi dibuat semenarik mungkin (gambar 4). Penyampaian materi juga dibuat senyaman mungkin menggunakan bahasa yang mudah dimengerti.

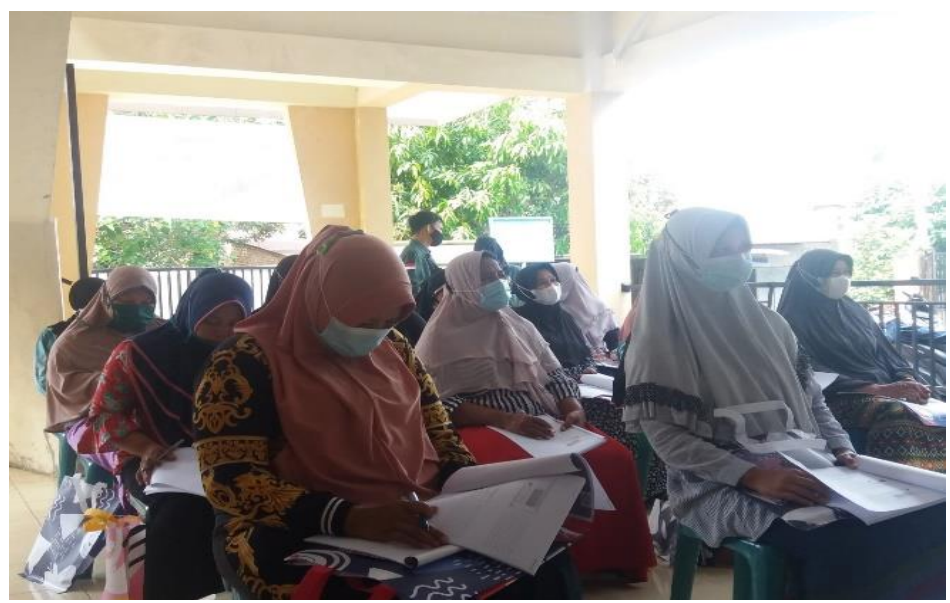

Gambar 5. Peserta mengikuti kegiatan dengan atusias

Pada gambar 5 diatas terlihat bahwa peserta dengan seksama mengikuti kegiatan pelatihan dengan memperhatikan narasumber dan membaca modul yang dibagikan kepada peserta. Setelah penyampaian materi, kegiatan selanjutnya adalah pendampingan. Pada kegiatan ini peserta diminta langsung mempraktekkan penggunaan aplikasi buku kas. Perserta benar-benar di dampingi dalam penggunaan aplikasi step by step sesuai dengan materi yang telah disampaikan terlebih dahulu. Peserta juga dipersilahan untuk bertanya. Antusian terlihat jelas dari peserta karena para peserta bertindak aktif untuk mempraktekkan dan bertanya hal-hal yang belum dipahami. Pada gambar 6 terlihat bahwa salah satu narasumber sedang melakukan pendampingan kepada peserta.

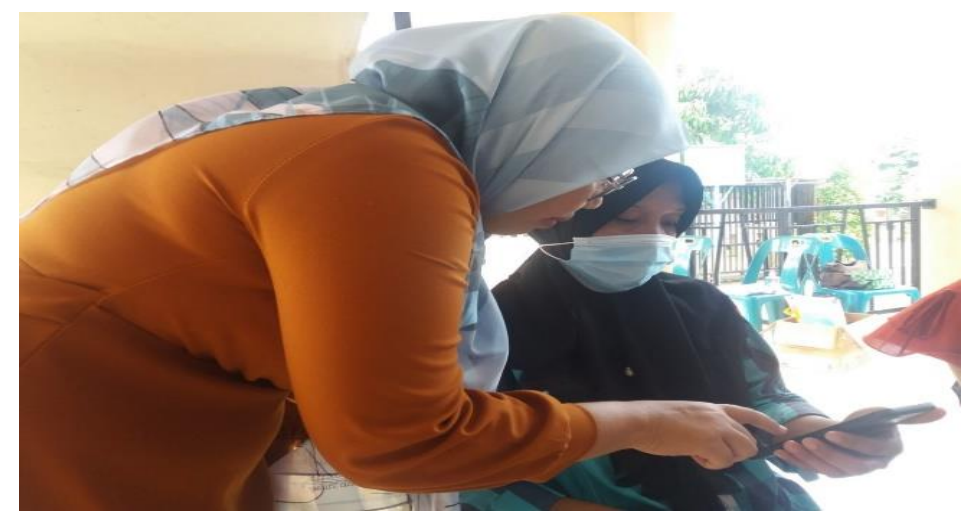

Gambar 6. Salah satu narasumber sedang membantu peserta menggunakan aplikasi manajemen keuangan

\subsection{Evaluasi}

Evaluasi dilakukan dengan milihat hasil pretest dan posttest peserta. Apakah ada peningkatan pengetahuan peserta setelah penyampaian materi oleh narasumber. 


\section{Journal of Social Responsibility Projects by Higher Education Forum}

Vol 2, No 2, November 2021, Page 68-72

ISSN 2723-1674 (Media Online)

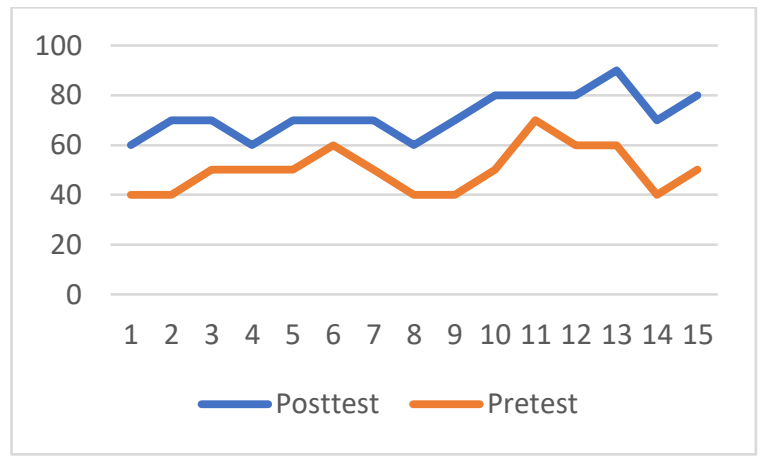

Gambar 7. Grafik Hasil Perbandingan nilai posttest dan pretest peserta.

Berdasarkan grafik pada Gambar 7 di atas diketahui bahwa ada peningkatan nilai yang peroleh dari para peserta. Hal ini menunjukkan bahwa peserta memahami materi yang disampaikan oleh narasumber. Berdasarkan gambar grafik juga dikaetahui bahwa nilai rata-rata posttest peserta adalah 70, sedangkan rata-rata pretest peserta adalah 50 .

Evaluasi juga dilakukan terhadap pelaksanaan kegiatan. Untuk mengetahui bagaimana tanggapan peserta tentang pelaksanaan kegiatan, seperti yang terlihat pada Gambar 8 peserta diminta untuk mengisi kuisoner. Hasil dari jawaban kuisoner peserta mengatakan bahwa pelaksanaan kegiatan sudah baik dan materi yang disampaikan juga sudah sesuai dengan tema kegiatan.

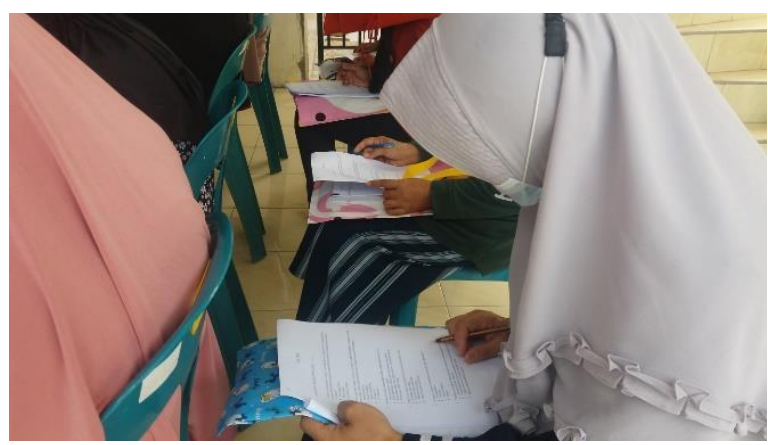

Gambar 8. Peserta Mengisi Kuisoner yang dibagikan tim pelaksana kegiatan pengabdian

\section{KESIMPULAN}

Kegiatan pengabdian kepada masyrakat yang dilaksanakan berjalan dengan lancar dan sudah sesuai dengan tujuan akhir yang ingin dicapai yaitu adanya peningkatan pengetahuan bagi ibu-ibu anggota PKK dalam mengelola atau memanajemen keuangan usaha yang kembangangkan. Permasalahan mitra yaitu kesulitan menggunakan aplikasi manajemen keuangan sudah terselesaikan. Melalui pendampingan yang dilakukan masing-masing ibu-ibu anggota PKK tersebut sudah memiliki akun di salah satu aplikasi manajemen keuangan tersebut, dan sudah bisa digunakan untuk pencatatan setiap transaksi, hutang sampai pencatatan stok barang yang masih tersedia.

\section{DAFTAR PUSTAKA}

Dewi M.W, Kusuma I.L , Kristiyanti LMS. 2021. Sosialisasi Pengelolaan Keuangan Rumah Tangga Di Masa Pandemi Covid 19. Jurnal Budimas. 3(1)

Fathah R. N and Widyaningtyas R.D. 2020. Pelatihan Manajemen Keuangan Bagi Pelaku Usaha Mikro Kecil dan Menengah (UMKM) Di Sekitar UNISA. The 11 th University Research Colloquium.

Hetika, Sari Y.P, Farida I, Harjanti R.S. 2020. Mengelola Keuangan Usaha Secara Praktis Dengan Aplikasi Keuangan Berbasis Android Pada Usaha Manufaktur Di Kota Tegal. MATAPPA: Jurnal Pengabdian Kepada Masyarakat. 3(1)

Kristani L.S et all, 2021. Manajemen Keuangan Untuk Meningkatkan Perekonomian Keluarga Kampung Serua Poncol Tangerang Selatan. Jurnal PADMA: Pengabdian Dharma Masyarakat. 1(1)

Supriyono E, Sumarta N.H, Narulitasari D. 2021. Pengelolaan Keuangan Keluarga Pada Ibu Rumah Tangga Pemilik Umkm Sebagai Masyarakat Terdampak Covid-19 Di Kelurahan Kauman, Surakarta. Jurnal Budimas. 3(1) 